\title{
Forest typological features of herb species abundance distributions of pine forests in the Ural Mountains
}

\author{
Natalya Ivanova* \\ Institute Botanic Garden Ural Branch of Russian Academy of Sciences, 620144, Yekaterinburg, \\ Russian Federation
}

\begin{abstract}
The problem of preserving biodiversity in the face of human influence and climate change is one of the most pressing problems of modern ecology. The aim of the study is to identify the characteristics of herb SAD for various mountain pine forest types in the Middle Urals. Studies conducted in various types of pine forests have shown that the SAD method is an effective method for analysing the species structure and biodiversity of forest vegetation. The results presented in the form of graphs are clear, intuitive and easy to interpret. The use of approximations by several functions and comparison with theoretical distributions allows a deeper understanding of the features of forest species diversity
\end{abstract}

\section{Introduction}

The problem of preserving biodiversity in the face of human influence and climate change is one of the most pressing problems of modern ecology [1]. Finding solutions is recognized as important for preserving the stability of the biosphere and at the same time understands the complexity, versatility of the problem, as well as the unresolved nature of many issues. The problem is significantly complicated by the lack of a generally accepted system of indicators of biodiversity and methods for studying it. Among the relatively new methods, the species abundance distributions (SAD) attracts special attention of researchers, since SAD is a fundamental regularity in ecology [2,3]. This approach allows us to obtain graphs that are determined not only by a dominant species, but also by many low-abundance species, and makes it possible to compare different plant communities even with a large difference in species composition. Studies conducted in various regions have shown good effectiveness of SAD [3-5], including for the Ural Mountains [6, 7]. Forest management, reforestation and nature protection in the Russian Federation are based on the forest typology [8]. Therefore, it is very important to know the forest-typological features of plant biodiversity and its determining factors. However, this problem is not solved for the Ural Mountains.

The aim of the study is to identify the characteristics of herb SAD for various mountain pine forest types in the Middle Urals.

* Corresponding author: i.n.s@bk.ru 


\section{Materials and Methods}

\subsection{Study area}

The study area is located on the eastern macroslope of the Middle Urals. Relief is lowmountain with elevations ranging from 250 to $500 \mathrm{~m}$ above sea level. The frost-free season does not exceed 115 days [8]. Potential vegetation is represented by various types of southern taiga forests, among which pine forests with birch and larch in the composition predominate. The systematization of forest types is carried out on the basis of geographical and genetic typology $[9,10]$. A brief description of the forest types is given in the catalog [8].

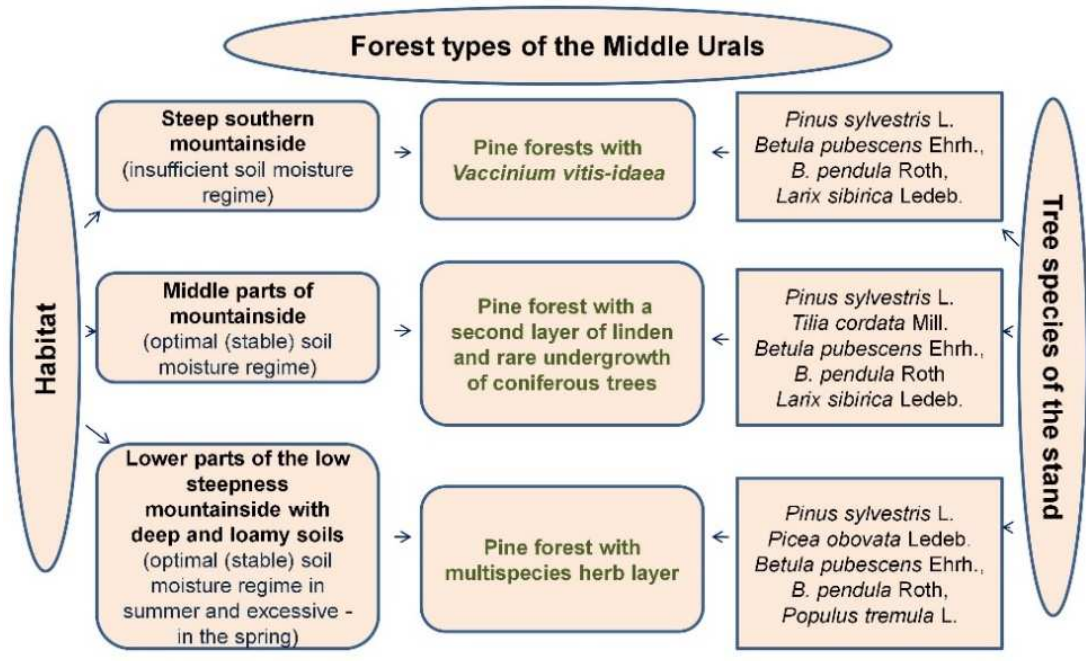

Fig. 1. Investigated forest types of the Ural Mountains

\subsection{Sampling, Measurements and Data Analysis}

We studied three forest types (on a sample plots of $0.25 \mathrm{ha}$ ), occupying different positions on the mountain slope (Fig. 1). The research methods were generally accepted in forest taxation and forest science [11]. The herb biomass was studied on 15 subplots with a size of $1 \times 1 \mathrm{~m}$. The values of the herb biomass are given in oven-dry state (drying was carried out at 105 to a constant mass). A detailed description of the stand structure and the tree undergrowth is given earlier [7, 12, 13]. The data analysis consisted in constructing SAD graphs, approximating it with power and exponential functions, and checking for compliance of the obtained SADs with the universal Gibbs (Motomura) and Pareto laws [2$5]$.

\section{Results and Discussion}

The different position in the relief of the studied forests is reflected in the stand composition and herb biomass (Fig. 1, Table 1). The maximum herb biomass is marked in the Pine forest with multispecies herb layer. A small coefficient of variation $(\mathrm{Cv})$ indicates the uniformity of the development of the herb layer in this forest type. The minimum biomass is observed in the Pine forest with a second layer of linden and rare undergrowth 
of coniferous plants, and $\mathrm{Cv}$ here is the maximum. A high $\mathrm{Cv}$ indicates an uneven distribution of the herb layer in this forest type (Table 1).

Table 1. General characteristics of the stand and herb biomass investigated forests

\begin{tabular}{|c|c|c|c|c|}
\hline Forest Type & $\begin{array}{c}\text { Stand } \\
\text { age, } \\
\text { years }\end{array}$ & $\begin{array}{c}\text { Basal } \\
\text { area, } \\
\mathbf{m}^{2} / \mathbf{h a}\end{array}$ & $\begin{array}{c}\text { Oven-dry } \\
\text { herb layer } \\
\text { biomass, } \\
\mathbf{g} / \mathbf{m}^{2}\end{array}$ & $\begin{array}{c}\text { Cv of } \\
\text { oven-dry } \\
\text { biomass, } \\
\mathbf{\%}\end{array}$ \\
\hline Pine forests with Vaccinium vitis-idaea & 160 & 44 & 78,0 & 77,5 \\
\hline $\begin{array}{c}\text { Pine forest with a second layer of linden } \\
\text { and rare undergrowth of coniferous plants }\end{array}$ & 140 & 32 & 69,7 & 78,0 \\
\hline Pine forest with multispecies herb layer & 150 & 42 & 89,8 & 12,6 \\
\hline
\end{tabular}

Note: $\mathrm{Cv}$ - coefficient of variation

For more information about the species structure and diversity, see the SAD graphs (Fig. 2-4). The SAD length (number of ranks) indicates species diversity, and the slope angle reflects the irregular of the distribution of herb biomass between species.

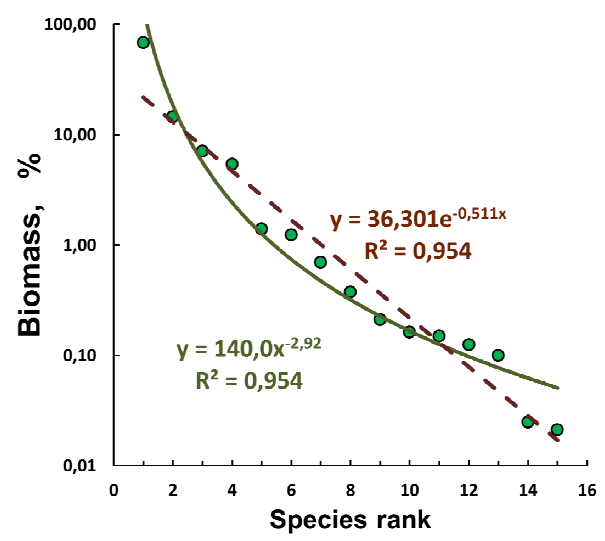

Fig. 2. Herb SADs in 160-years-old pine forests with Vaccinium vitis-idaea: points - relative species biomass (\%); approximation: solid line - power function; dotted line - exponential function; species rank: 1 - Vaccinium myrtillus, 2 - Calamagrostis arundinacea, 3 - Vaccinium vitis-idaea, 4 Linnaea borealis, 5 - Rubus saxatilis, 6 - Solidago virgaurea, 7 - Antennaria dioica, 8 Maianthemum bifolium, 9 - Hieracium umbellatum, 10 - Pyrola rotundifolia, 11 - Luzula pilosa, 12 - Chimaphila umbellata, 13 - Fragaria vesca, 14 - Melampyrum pratense, 15 - Viola canina 


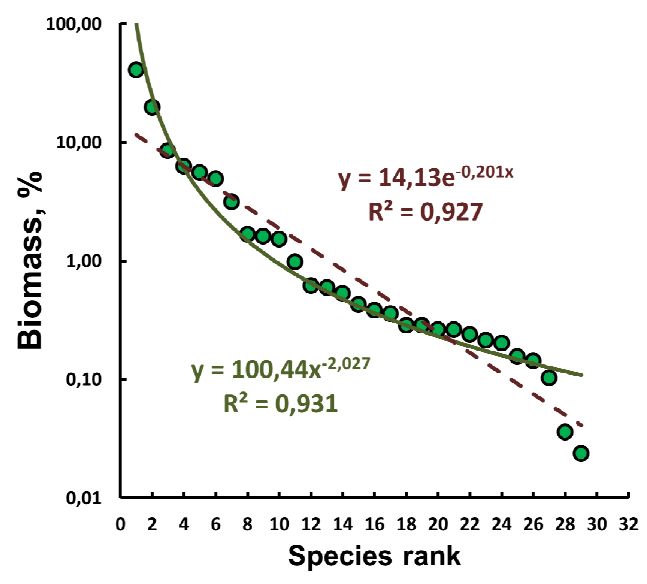

Fig. 3. Herb SADs in 140-years-old pine forests with a second layer of linden and rare undergrowth of coniferous plants: points - relative species biomass (\%); approximation: solid line - power function; dotted line - exponential function; species rank: 1 - Vaccinium myrtillus, 2 - Vaccinium vitis-idaea, 3 - Calamagrostis arundinacea (L.), 4 - Carex digitata, 5 - Brachypodium pinnatum, 6 - Linnaea borealis, 7 - Ramischia secunda, 8 - Rubus saxatilis, 9 - Maianthemum bifolium, 10 - Pteridium aquilinum, 11 - Lathyrus vernus, 12 - Galium boreale, 13 - Geranium sylvaticum, 14 - Melica nutans, 15 - Cirsium heterophyllum, 16 - Pyrola rotundifolia, 17 - Fragaria vesca, 18 - Succisa pratensis, 19 - Dryopteris carthusiana, 20 - Trifolium lupinaster, 21 - Veronica chamaedrys, 22 Potentilla erecta, 23 - Solidago virgaurea, 24 - Trientalis europaea, 25 - Hieracium umbellatum, 26 - Viola canina, 27 - Luzula pilosa, 28 - Melampyrum pratens, 29 - Lathyrus pisiformis

SAD graphs allow you to visually assess the species diversity, the uniformity of the distribution of abundance between species, and the rate of decline in biomass with increasing rank, and it is very convenient in practice for comparative analysis. The approximation by several functions provides additional information, including the correspondence of the resulting SAD to the theoretical distribution law. The closer the points are to the theoretical line, the greater the correspondence to the theoretical distribution law. We used power and exponential functions. For the forests studied, $r^{2}$ showed the applicability of both functions (Fig. 2-4). However, there are special features. Different SAD segments (for example, the beginning, middle, or end) show proximity to different theoretical distributions. The exponential function indicates that SAD corresponds to the theoretical Gibbs (or Motomura) law, and the power function indicates the Pareto law [14]. The initial SAD segment is more consistent with the Pareto law for all the forests studied. The average SAD segment can be approximated equally successfully by both power and exponential functions. And the last segment of SAD is better approximated by the exponential function and corresponds more to Motomura's law for all the forests studied. Additional benefits for practical application can be derived from the coefficients of the approximating functions. It can act as a kind of diversity index (evenness index). 


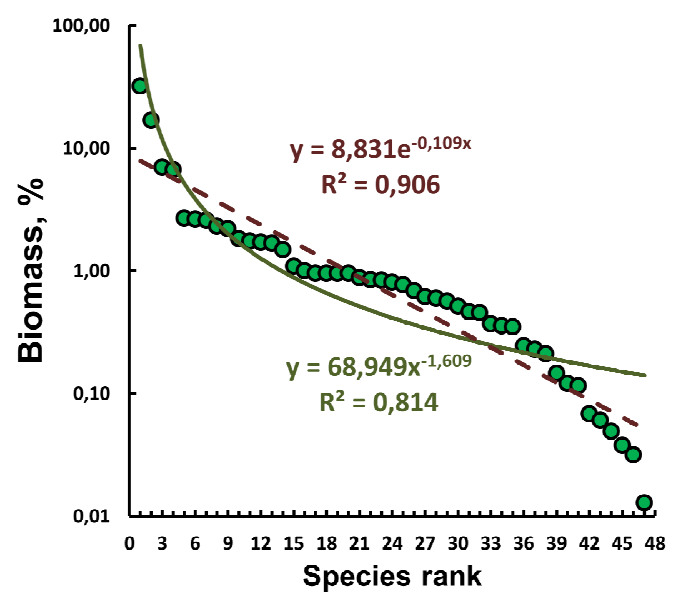

Fig. 4. Herb SADs in 160-years-old pine forest with multispecies herb layer: points - relative species biomass (\%); approximation: solid line - power function; dotted line - exponential function; species rank: 1 - Calamagrostis arundinacea, 2 - Brachypodium pinnatum, 3 - Rubus saxatilis, 4 - Carex nigra, 5 - Galium boreale, 6 - Thalictrum minus, 7 - Heracleum sibiricum, 8 - Aconitum septentrionale, 9 - Lathyrus vernus, 10 - Geranium sylvaticum, 11 - Vaccinium myrtillus, 12 Lathyrus gmelinii, 13 - Stellaria holostea, 14 - Cerastium pauciflorum, 15 - Angelica sylvestris, 16 Trollius europaeus, 17 - Aegopodium podagraria, 18 - Viola mirabilis, 19 - Cirsium heterophyllum, 20 - Vicia cracca, 21 - Orthilia secunda, 22 - Vaccinium vitis-idaea, 23 - Atragene sibirica, 24 Pulmonaria mollis, 25 - Bupleurum longifolium ssp. aureum, 26 - Adenophora liliifolia, 27 Platanthera bifolia, 28 - Maianthemum bifolium, 29 - Oxalis acetosella, 30 - Adonis vernalis, 31 Vicia sylvatica, 32 - Lilium martagon, 33 - Fragaria vesca, 34 - Pyrola minor, 35 - Lathyrus pratensis, 36 - Luzula pilosa, 37 - Solidago virgaurea, 38 - Pyrola rotundifolia, 39 - Melica nutans, 40 - Paris quadrifolia, 41 - Linnaea borealis, 42 - Moneses uniflora, 43 - Trientalis europaea, 44 Lathyrus pisiformis, 45 - Anthriscus sylvestris, 46 - Veronica chamaedrys, 47 - Viola canina

\section{Conclusion}

Studies conducted in various types of pine forests have shown that the SAD method is an effective method for analysing the species structure and biodiversity of forest vegetation. The results presented in the form of graphs are clear, intuitive and easy to interpret. The use of approximations by several functions and comparison with theoretical distributions allows a deeper understanding of the features of forest species diversity. In general, SAD can be recommended for environmental research and nature conservation, and this method can also help in greening when selecting the composition of artificial plant communities to increase their sustainability and enhance ecosystem functions.

The work was carried out within the framework of the state task of the Botanical Garden of the Ural branch of RAS.

\section{References}

1. R. Maiti, H. G. Rodriguez, N. S. Ivanova, Autoecology and Ecophysiology of Woody Shrubs and Trees: Concepts and Applications (John Wiley \& Sons, Ltd, 2016)

2. Th. J. Matthews, R. J. Whittaker, Journal of Applied Ecology 52 (2014)

3. L. Tan, P. Zhang, X. Zhao, C. Fan, C. Zhang, Y. Yan, K. Von Gadow, iForest 13 (2020)

4. S. J. Alavi, R. Veiskarami, O. Esmailzadeh, K. Gadow, Forests 11 (2020). 
5. R. A. Fd. Lima, P. A. Condé, C. Banks-Leite, R. C. Campos, M. I. M. Hernández, R. R. Rodrigues, PLoS ONE 15(9) (2020)

6. N. Ivanova, I. Petrova, Species abundance distributions: investigation of adaptation mechanisms of plant communities, E3S Web of Conferences: International Scientific and Practical Conference "Fundamental and Applied Research in Biology and Agriculture: Current Issues, Achievements and Innovations" 254 (2021)

7. N. S. Ivanova, E. S. Zolotova, G. Li, Ecological Questions 32(2) (2021)

8. B. P. Kolesnikov, R. S. Zubareva, E. P. Smolonogov, Forest vegetation conditions and forest types of Sverdlovsk oblast. Field guidance. (Sverdlovsk, Scientific Training Center the USSR Academy of Sciences, 1973)

9. V. Fomin, N. Ivanova, A. Mikhailovich, Genetic Forest Typology as a Scientific and Methodological Basis for Environmental Studies and Forest Management, IOP Conference Series: Earth and Environmental Science 609(1), 6th World Multidisciplinary Earth Sciences Symposium 7-11 September 2020, Prague, Czech Republic (2020)

10. V. Fomin, A. Mikhailovich, S. Zalesov, A. Popov, G. Terekhov, Baltic Forestry 27(1), (2021)

11. N. Ivanova, Biology, Productivity and Bioenergy of Timber-Yielding Plants: An Experimental Technology (SpringerBriefs in Plant Science. Springer, Cham, 2017)

12. N. S. Ivanova, International Journal of Bio-resource and Stress Management 10 (2019)

13. N. Ivanova, I. Petrova, Age structure of coniferous saplings in mountain old-growth forests of the Middle Urals, E3S Web of Conferences: International Scientific and Practical Conference «Actual Problems of Ecology and Environmental Management» 265 (2021)

14. R. Whittaker, Communities and Ecosystems (Moscow, Progress, 1980) 